\section{Assessing the vigor of cowpea seeds using the Vigor-S software}

\author{
Carlos Henrique Queiroz Rego ${ }^{1 *}$ (D) Silvio Moure Cicero ${ }^{1}$ (D) Fabiano França- \\ Silva $^{1}{ }^{1 D}$, Francisco Guilhien Gomes-Junior ${ }^{1}$
}

\begin{abstract}
The use of computational resources to assess the physiological potential of seeds has attracted the attention of researchers and professionals in the seed sector. The aim of this study was to evaluate the vigor of cowpea seeds using the Vigor-S software (Automated Seed Vigor Analysis System), in comparison to the information provided by traditional vigor tests that are recommended for the species. Seven seed lots of the cultivar BRS Guariba were used. They underwent germination and seed vigor assessment by testing first germination count, accelerated aging, electrical conductivity, seedling emergence, speed of seedling emergence and use of Vigor-S, an automated image system for seedling assessment, in two evaluation periods. The data underwent analysis of variance, in a completely randomized design and their means were compared by the Scott-Knott test ( $p \leq$ $0.05)$. An analysis was made of the correlation between the vigor tests traditionally used and the variables provided by Vigor-S. Using the Vigor-S software for automated image analysis of cowpea seedlings three days after sowing is an efficient alternative to detect differences in vigor between seed lots, similarly to traditional seed vigor evaluations.
\end{abstract}

Index terms: Vigna unguiculata (L.) Walp, image analysis, seedling performance.

\section{Avaliação do vigor de sementes de feijão-caupi por meio do software Vigor-S}

RESUMO: O uso de recursos computacionais para a avaliação do potencial fisiológico de sementes tem atraído atenção de pesquisadores e profissionais do setor sementeiro. 0 objetivo deste estudo foi a avaliação do vigor de sementes de feijão-caupi com a utilização do software Vigor-S (Sistema de Análise Automatizada do Vigor de Sementes). Foram utilizados sete lotes de sementes do cultivar BRS Guariba que foram submetidos aos testes de primeira contagem de germinação, envelhecimento acelerado, condutividade elétrica, emergência de plântulas, velocidade de emergência de plântulas e sistema computadorizado de imagens de plântulas (Vigor-S), avaliados em duas épocas. Os dados foram submetidos a análise da variância, em delineamento inteiramente casualizado e suas médias comparadas pelo teste de Scott-Knott $(p \leq 0,05)$ e a análise de correlação entre os testes de vigor tradicionalmente utilizados e as variáveis fornecidas pelo Vigor-S. A análise computadorizada de imagens de plântulas de feijão-caupi com três dias após a semeadura por meio do software Vigor-S é uma alternativa eficiente para detectar diferenças de vigor entre os lotes de sementes, de forma similar às avaliações tradicionais do vigor de sementes.

Termos para indexação: Vigna unguiculata (L.) Walp, análise de imagens, desempenho de plântulas.
Journal of Seed Science, v.43, e202143018, 2021

http://dx.doi.org/10.1590/ 2317-1545v43244858
$*$ Corresponding author
E-mail: carlosqueirozagro@gmail.com

Received: $10 / 22 / 2020$

Accepted: 6/14/2021

${ }^{1}$ Departamento de Produção Vegetal, USP/ESALQ, Caixa Postal 9, 13418-900 - Piracicaba, SP, Brasil. 


\section{INTRODUCTION}

The cowpea (Vigna unguiculata L. Walp) is an important plant species for the North, Northeast and Mid-West regions of Brazil, whose production of seeds and grains is estimated at 122 and 712.6 thousand tons, respectively (Brasil, 2020; CONAB, 2020). One of the most common problems faced by farmers when growing this species is low seed quality. Many seeds are multiplied and stored by producers themselves between agricultural cycles (Smiderle et al., 2017), which may further increase the loss of physiological quality before sowing is actually performed.

Quick detection of the vigor of cowpea seeds is essential to avoid loss of seed quality (and, consequently, commercial losses) and to enable sowing. Thus, there has been ongoing research into alternative methods for seed vigor assessment to compare their efficiency with that of traditional vigor tests. An example is automated seed vigor assessment, e.g., automated analysis of seedling images, which is a feasible and promising alternative for seed vigor assessment (Castan et al., 2018).

The use of this technique has been increasingly frequent, especially with the development of systems based on the use of scanners to capture images - for example, the software Seed Vigor Imaging System - SVIS ${ }^{\circ}$, initially developed to assess lettuce seed vigor (Sako et al., 2001) and later adapted to other species such as soybeans (Wendt et al., 2014) and beans (Gomes-Junior et al., 2014). More recently, as a result of a partnership between the Universidade de São Paulo (USP/ESALQ) and the Brazilian Agricultural Research Corporation (Embrapa Instrumentação), and supported by the Fundação de Amparo à Pesquisa do Estado de São Paulo (FAPESP), a group of researchers have developed an "Automated Seed Vigor Analysis System (Vigor-S)", whose vigor assessment efficiency has already been proven for corn seeds (Castan et al., 2018), common beans (Medeiros et al., 2019), soybeans (Rodrigues et al., 2020) and melon (Leite et al., 2020).

Notably, Vigor-S was developed with the objective of assessing the physiological potential of corn and soybean seeds. Although its simple, practical and fast seed quality assessment has been effectively applied to some other particular species, the use of the automated seed vigor analysis methodology with the software Vigor-S is not yet established for cowpea seeds.

Given the need to extend this methodology to other species, the aim of this study was to evaluate the efficiency of the technique of automated seedling analysis using the software Vigor-S to detect the vigor of cowpea seeds in different lots, and compare the outcomes with the information provided by traditional vigor tests recommended for the species.

\section{MATERIAL AND METHODS}

The experiment used certified cowpea seeds from seven lots of cultivar BRS Guariba, produced in the 2017/2018 crop year. The seeds were donated by the company Sementes Tomazetti, located in the municipality of Primavera do Leste, Mato Grosso, Brazil. Characterization of the lots was performed by applying the germination test, traditional vigor tests, and automated seedling analysis by Vigor-S, as described below. The assessments were carried out in two different periods with a four-month interval. During the experiment, the seeds were placed in a porous package and stored in a dry chamber $\left(20^{\circ} \mathrm{C}\right.$ and $50 \%$ relative humidity).

Moisture content: determined by the greenhouse method; two replicates with approximately $4.0 \mathrm{~g}$ of seeds for each lot were maintained in a greenhouse at $105 \pm 3{ }^{\circ} \mathrm{C}$ for 24 hours, according to the Rules for Seed Testing (Brasil, 2009). The results were expressed as a percentage (wet basis).

Germination: the test used four replicates of fifty seeds per lot, with sheets of paper towel as substrate, previously moistened with water at 2.5 times the dry paper weight and kept in a germinator at $25^{\circ} \mathrm{C}$, in the dark. The assessments were performed on the fifth (first germination count) and eighth day after sowing by counting the number of normal seedlings. The results were expressed as percentage of normal seedlings (Brasil, 2009).

Accelerated aging: four replicates of fifty seeds from each lot were distributed in a single layer on a suspended 
screen inside a transparent plastic box $(11 \times 11 \times 3 \mathrm{~cm})$, containing $40 \mathrm{~mL}$ of distilled water. The plastic boxes were kept in a BOD incubator, set at $42{ }^{\circ} \mathrm{C}$, for 48 hours, according to the methodology described by Dutra and Teófilo (2007). Subsequently, the aged seeds underwent the germination test, as described above; the assessments were carried out on the fifth day after the germination test had been installed, and the number of normal seedlings was counted (Brasil, 2009). The results were expressed as a percentage.

Electrical conductivity: four replicates of fifty seeds were accurately weighed on a scale and subsequently placed to soak in plastic cups $\left(200 \mathrm{~mL}\right.$ ) containing $75 \mathrm{~mL}$ of deionized water and kept in a germinator for sixteen hours at $25^{\circ} \mathrm{C}$ (Dutra et al., 2006). The electrical conductivity readings were taken with the aid of a "DIGIMED DM-31" conductivity meter and the mean values were expressed as $\mu \mathrm{S} . \mathrm{cm}^{-1} \cdot \mathrm{g}^{-1}$ of seeds.

Seedling emergence in sand: four replicates of fifty seeds from each lot were distributed over a $6 \mathrm{~cm}$ layer of medium textured sand, placed in plastic boxes $(32 \times 28 \times 10 \mathrm{~cm})$. After sowing, the seeds were covered with a thin layer of $3 \mathrm{~cm}$ of sand and, subsequently, irrigation was carried out to $60 \%$ of the substrate's water retention capacity. The assessments were performed on a daily basis by counting the number of emerged seedlings until the seventh day after the installation of the test. Average seedling emergence percentage was determined for each lot and the seedling emergence speed index (ESI) was calculated, using the method proposed by Maguire (1962).

Automated seedling analysis (Vigor-S): five replicates of twenty seeds were used for each lot, distributed in two rows in the upper third on two sheets of paper towel and covered with a third sheet (Figure 1a). The substrate was moistened with water at 2.5 times the substrate weight, and the paper towel rolls were kept in a germinator at $25{ }^{\circ} \mathrm{C}$, in the dark (Figure 1b). After three days, the seedlings from each replicate were transferred from the paper towel rolls to a $30 \mathrm{~cm} \times 22 \mathrm{~cm}$
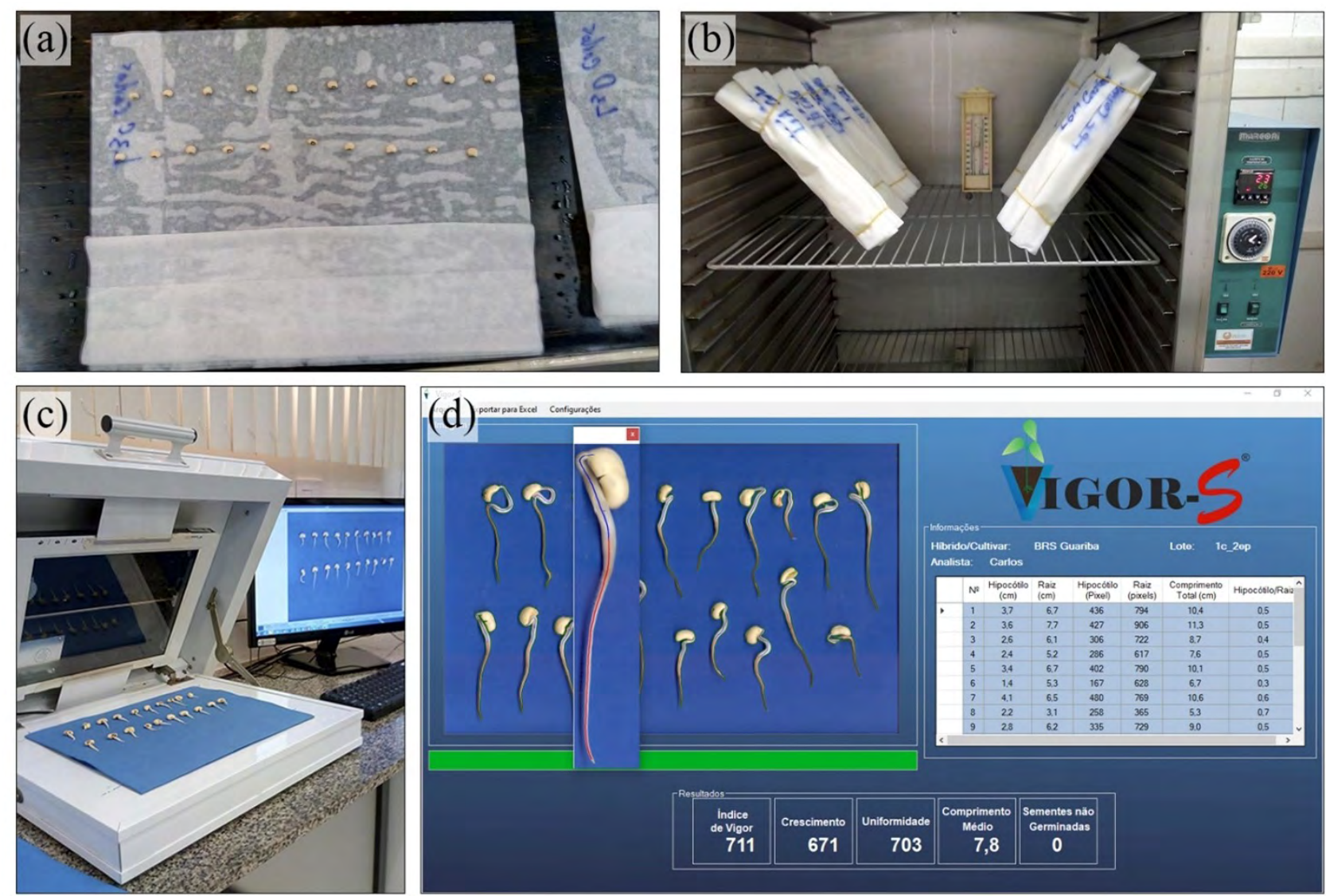

Figure 1. Steps for computer analysis: installation of the seed germination test (a); substrate positioned at a nearvertical angle ( 75 to $85^{\circ}$ from the horizontal axis) (b); image acquisition by an inverted scanner (c) and analysis window of cowpea seedlings scanned and processed by the software Vigor-S (d). 
blue Ethylene Vinyl Acetate (EVA) sheet, corresponding to the usable area of an HP Scanjet 200 scanner, installed upside down inside an aluminum box ( $60 \times 50 \times 12 \mathrm{~cm})$, adjusted to a 300-dpi resolution and connected to a computer (Figure 1c). In the software, the following settings were applied: for growth and uniformity values, the percentages of $70 \%$ and $30 \%$ were adopted, respectively; the hypocotyl and primary root values were set at $10 \%$ and $90 \%$, respectively. The images were processed by the software Vigor-S (Figure 1d) to determine the vigor and development uniformity indexes, within a range from 0 to 1000. Seed vigor was proportional to these values, according to Castan et al. (2018). In addition, average values were also determined for the length of all seedlings. Data were exported to a spreadsheet for subsequent analysis.

Statistical analysis: the data underwent analysis of variance in a completely randomized design, and the means were compared by the Scott-Knott test ( $p \leq 0.05)$. Pearson's correlation coefficients $(r)$ were calculated for all combinations between the vigor tests traditionally used and the variables provided by Vigor-S, in which the significance of $r$ values was determined by the t-test $(p \leq 0.05)$. Statistical analyses were performed using the software $R$, version 3.5 .1 ( $R$ Core Team, 2020). Correlation was analyzed on the basis of the classification proposed by Figueiredo-Filho et al. (2014), in which coefficients from 0.1 to 0.3 are considered as weak; from 0.4 to 0.6 , moderate; and above 0.7 , strong.

\section{RESULTS AND DISCUSSION}

The variation in moisture content between seed lots at the beginning of the assessments and after accelerated aging was not greater than two percentage points (Table 1); thus, it did not interfere with the performance of seed lots (Marcos-Filho, 2015a). Also, based on the analysis of variance (shown in Table 1), differences ( $\leq \leq 0.05$ ) were found in germination and vigor between the seed lots evaluated in the two assessment periods.

The findings of the germination test showed that lots 1, 3 and 4 were significantly better than the others in the first evaluation period; in the second period, the lots were more stratified: lots 1 and 3 had the highest germination potential, and lots 6, 7 and 2, the lowest potential, while the other lots had intermediate potential. In general, all lots showed germination percentages within the standards for commercialization of cowpea seeds in Brazil, which currently corresponds to a minimum of $80 \%$ germination (Brasil, 2013).

Table 1 shows that first count and accelerated aging tests indicated that lots 1, 3 and 4 had the greatest vigor; lot $2 \mathrm{had}$ less vigor and the other lots had an intermediate level of vigor in the first evaluation period. In the second assessment period, for first count, only lot 1 showed high vigor; lots 2 and 7 showed the least vigor again and the other lots had intermediate vigor. For accelerated aging, lots 1, 4, 3 and 5 had better results in comparison to the others.

In the electrical conductivity test in the first assessment period, lots 1 and 3 had more vigor than the others; in the second assessment period, lots 1 and 3 were the most vigorous again; by contrast, lots 2 and 7 were the least vigorous, while the other lots had intermediate performance. For seedling emergence, lots 1, 3 and 4 stood out in comparison to the others in the first assessment period, while in the second period, only lots 1 and 3 had the best performance in comparison to the other lots.

For emergence speed index, lots 1, 3 and 4 stood out, while lots 6 and 7 had the lowest performance and the others had intermediate performance in the first evaluation period; in the second period, in turn, lots 1, 3 and 5 stood out in comparison to the others. It can be seen that the behavior of the lots was similar in the two assessment periods; however, it is clear that there was some loss in the quality of the lots after storage, especially for lot 4: during the first assessment period, it had the best performances, while in the second period, it had an intermediate performance.

The differences in vigor of the seed lots used in this study were due to the fact that the lots showed variation in germination percentage. However, the use of vigor tests was necessary, especially to detect small differences in vigor (Marcos-Filho, 2015a). Among the various tests available, the accelerated aging test is one of the most sensitive and efficient for assessing seed vigor (Marcos-Filho, 2015b), as it allows establishing a direct relationship between seed behavior and seedling emergence in the field. In addition, it already has a standardized methodology that enables an adequate assessment of the vigor of cowpea seeds (Dutra and Teófilo, 2007). 
Table 1. Moisture content at the beginning of the assessments (MC); germination (G); first germination count (FGC); moisture content after accelerated aging (MCAA); accelerated aging (AA); electrical conductivity (EC); seedling emergence (SE) and seedling emergence speed index (ESI) in seven cowpea seed lots of cultivar BRS Guariba, in two assessment periods.

\begin{tabular}{|c|c|c|c|c|c|c|c|c|}
\hline \multirow{3}{*}{ Lots } & $\mathrm{MC}$ & G & FGC & MCAA & AA & EC & SE & ESI \\
\hline & \multicolumn{5}{|c|}{--o- } & $\mu S / \mathrm{cm} / \mathrm{g}$ & $\%$ & - index - \\
\hline & & \multicolumn{7}{|c|}{$1^{\text {st }}$ assessment } \\
\hline 1 & 9.3 & 99 a & $81 \mathrm{a}$ & 26.1 & $77 a$ & $179.77 \mathrm{a}$ & $97 \mathrm{a}$ & $10.94 \mathrm{a}$ \\
\hline 2 & 8.6 & $85 \mathrm{~b}$ & $60 c$ & 25.3 & $58 \mathrm{c}$ & $195.10 \mathrm{~b}$ & $84 \mathrm{~b}$ & $9.23 \mathrm{~b}$ \\
\hline 3 & 9.2 & $97 a$ & $81 \mathrm{a}$ & 26.4 & 75 a & $181.87 \mathrm{a}$ & 95 a & $10.35 \mathrm{a}$ \\
\hline 4 & 9.4 & $96 a$ & $75 \mathrm{a}$ & 25.7 & $71 \mathrm{a}$ & $187.46 \mathrm{~b}$ & $92 \mathrm{a}$ & $10.10 \mathrm{a}$ \\
\hline 5 & 9.1 & $91 b$ & $66 \mathrm{~b}$ & 25.9 & $64 \mathrm{~b}$ & $188.27 b$ & $86 b$ & $9.42 b$ \\
\hline 6 & 9.5 & $89 \mathrm{~b}$ & $61 \mathrm{~b}$ & 25.5 & $64 \mathrm{~b}$ & $193.76 \mathrm{~b}$ & $85 b$ & $8.69 c$ \\
\hline 7 & 8.5 & $88 \mathrm{~b}$ & $60 \mathrm{~b}$ & 25.8 & $64 \mathrm{~b}$ & $191.77 \mathrm{~b}$ & $83 \mathrm{~b}$ & $8.33 \mathrm{c}$ \\
\hline$(F)$ & - & $10.01 *$ & $24.27^{*}$ & - & $13.43^{*}$ & $4.20 *$ & $6.54^{*}$ & $11.72 *$ \\
\hline \multirow[t]{2}{*}{ CV (\%) } & - & 3.62 & 5.58 & - & 5.69 & 3.01 & 5.14 & 6.95 \\
\hline & & \multicolumn{7}{|c|}{$2^{\text {nd }}$ assessment } \\
\hline 1 & 8.3 & $98 \mathrm{a}$ & $68 \mathrm{~b}$ & 27.5 & $68 a$ & $224.82 \mathrm{a}$ & $98 \mathrm{a}$ & $10.87 \mathrm{a}$ \\
\hline 2 & 8.3 & $82 \mathrm{c}$ & $46 c$ & 27.4 & $53 \mathrm{~b}$ & $277.94 \mathrm{c}$ & $78 \mathrm{~b}$ & $8.45 b$ \\
\hline 3 & 8.1 & $97 a$ & $75 a$ & 27.9 & $65 a$ & $237.98 a$ & $94 \mathrm{a}$ & $10.45 \mathrm{a}$ \\
\hline 4 & 8.1 & $90 \mathrm{~b}$ & $66 \mathrm{~b}$ & 27.7 & $67 a$ & $243.49 b$ & $83 \mathrm{~b}$ & $9.28 \mathrm{~b}$ \\
\hline 5 & 8.3 & $89 \mathrm{~b}$ & $63 \mathrm{~b}$ & 27.9 & $63 a$ & $256.07 \mathrm{~b}$ & $85 b$ & $9.84 \mathrm{a}$ \\
\hline 6 & 8.1 & $86 c$ & $56 \mathrm{~b}$ & 27.4 & $60 \mathrm{~b}$ & 249.78 b & $82 b$ & $8.92 b$ \\
\hline 7 & 8.1 & $84 \mathrm{c}$ & $46 c$ & 28.1 & $57 \mathrm{~b}$ & $275.94 \mathrm{c}$ & $81 \mathrm{~b}$ & $8.70 \mathrm{~b}$ \\
\hline$(F)$ & - & $10.89 *$ & $36.64^{*}$ & - & $7.09 *$ & $16.52^{*}$ & $7.13^{*}$ & $12.07^{*}$ \\
\hline CV (\%) & - & 4.22 & 6.07 & - & 6.46 & 3.80 & 6.27 & 10.87 \\
\hline
\end{tabular}

Means followed by the same letter, in the columns, in each assessment period, do not differ statistically by the Scott-Knott test ( $p \leq 0.05)$; CV: coefficient of variation.

Another established methodology to assess the potential of cowpea seed lots is the electrical conductivity test (Dutra et al., 2006); lots whose seeds have intact cell systems result in lower conductivity values. As membrane integrity is reduced, higher electrical conductivity values are found in the test; in practice, this affects the initial development of the seedlings during germination.

Another important parameter when assessing the physiological quality of seeds is determined through the seedling emergence test; the most vigorous lots have seeds that can quickly and uniformly establish seedlings even when conditions are unfavorable. Dutra et al. (2007), when evaluating different cowpea genotypes using the seedling emergence test, found that low-vigor seeds compromised the percentage of emerged seedlings, and the uniformity and speed of seedling emergence.

The results of the variables obtained from Vigor-S (Table 2) were efficient in separating the cowpea seed lots. Based on the vigor index, lots 1 and 3 were identified as more vigorous in comparison to the others, in the first assessment period; however, in the second assessment period, lots 1, 3, 5, 4 and 6 were classified as more vigorous when compared to the others. For the uniformity index, in the first assessment period, lots 1, 3, 5 and 4 had the highest averages, in 
contrast to lot 7, which had the lowest average. In the second assessment period, lots 1, 3, 4, 5 and 6 stood out in comparison to lots 2 and 7. Finally, for total seedling length, in the two assessment periods, lots 1, 3 and 4 were considered to have the greatest vigor, while lots 2 and 7 were classified as having the least vigor. In general, the Vigor-S variables showed that lots 1 and 3 had high vigor while lots 2 and 7 had low vigor, in the two assessment periods. These results are similar to those of the vigor tests traditionally used.

The use of the vigor test to measure the performance of seedlings is based on the principle that seeds with high vigor will form more vigorous seedlings, reflecting the effectiveness of the mechanisms of repair, mobilization of reserves and synthesis of new tissues during germination (Marcos-Filho, 2015b). In this context, the manual seedling length test has been reported in the literature as efficient, and it is often used to assess the quality of seeds of different species (Nakagawa, 1999), although it is time-consuming and errors are frequently made by analysts. However, such errors are minimized by automated seedling analysis.

In addition to seedling length, the software Vigor-S also provides indexes of development uniformity and seedling vigor, which were efficient in classifying seed lots in the present study, i.e., they are effective variables in seed quality control programs (Silva et al., 2017). These variables are directly related to the stand, as the irregular emergence of seedlings leads to delays in the development and irregular growth of plants at various phenological stages, with losses in production (Marcos-Filho, 2015b). Importantly, seed lots with a high rate of development uniformity do not represent

Table 2. Vigor indexes (VI), growth uniformity index (UI) and total seedling length (TSL) in the software Vigor-S, in seven lots of cowpea seeds, cultivar BRS Guariba, in two assessment periods.

\begin{tabular}{|c|c|c|c|}
\hline \multirow{3}{*}{ Lots } & VI & UI & TSL \\
\hline & \multicolumn{2}{|c|}{-------- index -------------- } & $\mathrm{cm}$ \\
\hline & \multicolumn{3}{|c|}{$1^{\text {st }}$ assessment } \\
\hline 1 & 597.94 a & 778.46 a & $7.23 \mathrm{a}$ \\
\hline 2 & $448.24 \mathrm{c}$ & $617.20 \mathrm{c}$ & $5.43 \mathrm{~b}$ \\
\hline 3 & $586.72 \mathrm{a}$ & 758.46 a & $6.76 \mathrm{a}$ \\
\hline 4 & $546.58 \mathrm{~b}$ & 735.96 a & $6.65 \mathrm{a}$ \\
\hline 5 & $519 b$ & 736.16 a & $5.78 \mathrm{~b}$ \\
\hline 6 & $524.12 b$ & $681.72 b$ & $5.71 b$ \\
\hline 7 & $538.06 \mathrm{~b}$ & $668.94 \mathrm{~b}$ & $5.78 \mathrm{~b}$ \\
\hline$(\mathrm{F})$ & $13.95^{*}$ & $10.98^{*}$ & $9.86 *$ \\
\hline \multirow[t]{2}{*}{ CV (\%) } & 5.50 & 5.42 & 7.75 \\
\hline & \multicolumn{3}{|c|}{$2^{\text {nd }}$ assessment } \\
\hline 1 & $554.62 \mathrm{a}$ & 762.88 a & $7.19 \mathrm{a}$ \\
\hline 2 & $477.46 \mathrm{~b}$ & $603.98 c$ & $4.85 \mathrm{~b}$ \\
\hline 3 & $547.52 \mathrm{a}$ & 744.62 a & $6.79 \mathrm{a}$ \\
\hline 4 & $528.84 \mathrm{a}$ & $741.08 \mathrm{a}$ & $6.58 \mathrm{a}$ \\
\hline 5 & 539.96 a & 736.96 a & $5.86 \mathrm{~b}$ \\
\hline 6 & $528.56 \mathrm{a}$ & 729.58 a & $5.70 \mathrm{~b}$ \\
\hline 7 & $493.24 \mathrm{~b}$ & $643.82 \mathrm{~b}$ & $5.38 \mathrm{~b}$ \\
\hline$(F)$ & $4.49 *$ & 30.91* & $12.31 *$ \\
\hline CV (\%) & 5.75 & 3.41 & 8.78 \\
\hline
\end{tabular}

Means followed by the same letter, in the rows, do not differ statistically by the Scott-Knott test $(p \leq 0,05)$;

CV: coefficient of variation. 
a guarantee of well-developed seedlings, since poorly developed seedlings can present a high rate of uniformity. Thus, the development uniformity index should not be considered on its own; rather, further studies should check how it relates to other variables.

The simple correlation analysis (Figure 2) showed that the variables from automated seedling analysis were positively correlated with the tests traditionally used to assess seed vigor, with the exception of electrical conductivity. Seedling length showed a "strong" correlation with the accelerated aging test, which can be explained by the fact that these tests assess seedling performance. The other variables had "moderate" correlations with all tests, a behavior that may be due to the performance of the intermediate lots, which were ranked in different orders, depending on the test being used. In general, the correlation values indicated dependence between the variables, i.e., the results generated by Vigor-S can distinguish the quality of seed lots in a similar way to that of the traditional tests used to assess seed vigor.

There is a recurrent need to develop new technologies and improve existing techniques for evaluating the physiological potential of seeds, through the integration of new algorithms and hardware architecture (Dell'Aquila, 2009). Castan et al. (2018) evaluated the efficiency of the Vigor-S system in corn seeds, compared it to the software SVIS ${ }^{\circledR}$, and highlighted the following advantages: the assessment offers optimal use of the results, as it automatically provides the lengths of the parts that make up the seedlings; analysts do not need to interfere in the analysis as much because the software offers higher image resolution ( $300 \mathrm{dpi}$ ); data can be exported to the extensions of the software Excel. It is worth noting that the acquisition of the system has a lower cost, since all it needs is a scanner, because the system is available free of charge on the Internet through the following link: https://drive.google.com/open?id=0B8rVh_ veepVzdXMOMIJ1MOIOZEk.

As with other systems, it is expected that the application of Vigor-S will be extended to species other the one it was originally developed for. Medeiros et al. (2019) and Leite et al. (2020) reported positive correlations between the

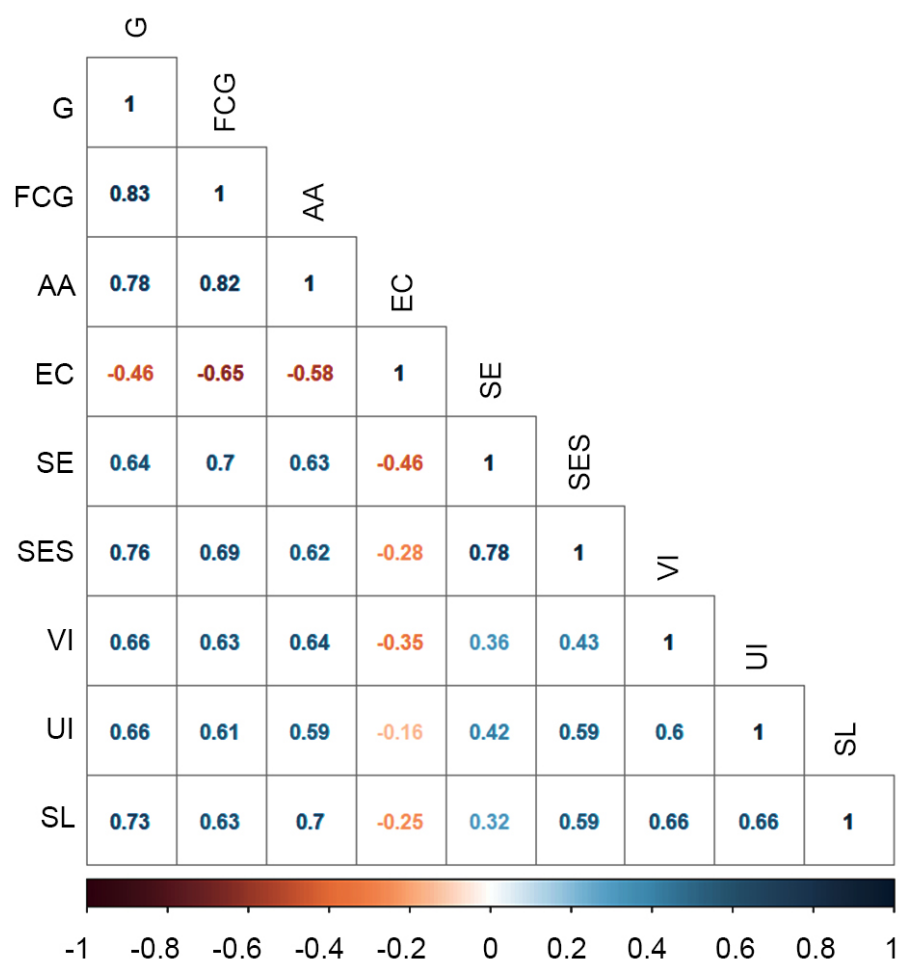

G: Germination; FGC: first germination count; AA: accelerated aging; EC: electrical conductivity; SE: seedling emergence; SES: seedling emergence speed; VI: vigor index; UI: uniformity index; SL: seedling length.

Figure 2. Pearson correlation $(r)$ among variables generated by traditional vigor tests and by computer-assisted analysis, using the software S-vigor, of seedlings of seven lots of cowpea seeds. 
variables found by the software and the tests traditionally used to assess the vigor of bean and melon seeds. Rodrigues et al. (2020) and Castan et al. (2018) also reported that the results they found when using Vigor-S were similar to those of tests traditionally recommended for assessing the vigor of soybean and corn seeds, respectively. In another study, Leite et al. (2018) concluded that Vigor-S can be used to detect phytotoxicity in soybean seedlings treated with different chemicals. Although studies on the Vigor-S system are recent, the findings of the present study are promising; also, it is expected that the system will soon be consolidated as an additional technique for seed quality control programs.

\section{CONCLUSIONS}

The automated analysis of seedling images using Vigor-S enables the distinction between cowpea lots based on seedling length and on vigor and growth uniformity indexes.

The results found using the Vigor-S system are similar to those of other traditional tests. Thus, it can be potentially used to evaluate seed vigor.

\section{ACKNOWLEDGEMENTS}

To the Conselho Nacional de Desenvolvimento Cientifico e Tecnológico (CNPq), for granting a scholarship to the first author.

\section{REFERENCES}

BRASIL. Ministério da Agricultura, Pecuária e Abastecimento. Padrões para produção e comercialização de sementes de feijãocaupi (Vigna unguiculata). Instrução Normativa no 45, de 17 de setembro de 2013. Diário Oficial da União, 2013.

BRASIL. Ministério da Agricultura, Pecuária e Abastecimento. Regras para análise de sementes. Ministério da Agricultura, Pecuária e Abastecimento. Secretaria de Defesa Agropecuária. Brasília: MAPA/ACS, 2009. 399p. https://www.gov.br/agricultura/pt-br/ assuntos/insumos-agropecuarios/arquivos-publicacoes-insumos/2946_regras_analise_sementes.pdf

BRASIL. Ministério da Agricultura, Pecuária e Abastecimento. SIGEF - Controle da Produção de Sementes e Mudas - Indicadores. Brasília, DF, 2020. Available on: http://indicadores.agricultura.gov.br/sigefsementes/index.htm . Accessed on: 10 out. 2020.

CASTAN, D.O.C.; GOMES-JUNIOR, F.G.; MARCOS-FILHO, J. Vigor-S, a new system for evaluating the physiological potential of maize seeds. Scientia Agricola, v.75, n.2, p.167-172, 2018. http://dx.doi.org/10.1590/1678-992x-2016-0401

CONAB. Companhia Brasileira de Abastecimento. Acompanhamento da safra brasileira de grãos - décimo segundo levantamento, safra 2019/2020. Available on: https://www.conab.gov.br/info-agro/safras/graos/boletim-da-safra-de-graos . Accessed on: 10 out. 2020.

DELL'AQUILA, A. Digital imaging information technology applied to seed germination testing. A review. Agronomy for Sustainable Development, v.29, n.1, p.213-221, 2009. https://doi.org/10.1051/agro:2008039

DUTRA, A.S.; MEDEIROS-FILHO, S.; TEÓFILO, E.M. Condutividade elétrica em sementes de feijão caupi. Revista Ciência Agronômica, v.37, n.2, p.166-170, 2006. http://ccarevista.ufc.br/seer/index.php/ccarevista/article/view/195/189

DUTRA, A. S.; TEÓFILO, E.M. Envelhecimento acelerado para avaliar o vigor de sementes de feijão caupi. Revista Brasileira de Sementes, v.29, n.1, p.193-197, 2007. https://doi.org/10.1590/S0101-31222007000100027

DUTRA, A.S.; TEÓFILO, E.M.; MEDEIROS-FILHO, S.; DIAS, F.T.C. Qualidade fisiológica de sementes de feijão caupi em quatro regiões do estado do Ceará. Revista Brasileira de Sementes, v.29, n.2, p.111-116, 2007. https://doi.org/10.1590/S0101-31222007000200015

FIGUEIREDO-FILHO, D.B.; ROCHA, E.C.; SILVA-JUNIOR, J.A.; PARANHOS, R.; NEVES, J.A.B.; SILVA, M.B. Desvendando os mistérios do coeficiente de correlação de Pearson: o retorno. Leviathan, n.8, p.66-95, 2014. https://doi.org/10.11606/issn.2237-4485. lev.2014.132346 
GOMES-JUNIOR, F.G.; CHAMMA, H.M.C.P.; CICERO, S.M. Automated image analysis of seedlings for vigor evaluation of common bean seeds. Acta Scientiarum. Agronomy, v.36, n.2, p.195-200, 2014. https://doi.org/10.4025/actasciagron.v36i2.21957

LEITE, C.A.M.; FRANÇA-NETO, J.B.; KRZYZANOWSKI, F.C.; GOMES-JUNIOR, F.G. Validação do sistema de análise de imagens Vigor-S para a determinação de fitotoxicidades em plântulas de soja. XIII Jornada Acadêmica da Embrapa Soja, 2018. p.130-137.

LEITE, M.D.S.; TORRES, S.B.; GOMES-JUNIOR, F.G.; REGO, C.H.Q.; PAIVA, E.P.D.; LEITE, T.D.S. Viability of seedling image analysis (Vigor-S) to determine the physiological potential of melon seeds. Journal of Seed Science, v.42, e202042043, 2020. http://dx.doi. org/10.1590/2317-1545v42237826

MAGUIRE, J.D. Speed of germination - aid in selection and evaluation for seedling emergence and vigor. Crop Science, v.2, n.2, p.176-177, 1962. https://doi.org/10.2135/cropsci1962.0011183X000200020033x

MARCOS-FILHO, J. Fisiologia de Sementes de Plantas Cultivadas. Londrina: ABRATES, 2015a. 660p.

MARCOS-FILHO, J. Seed vigor testing: an overview of the past, present and future perspective. Scientia Agricola, v.72, n.4, p.363374, 2015b. https://doi.org/10.1590/0103-9016-2015-0007

MEDEIROS, A.D.; SILVA, L.J.; CAPOBIANGO, N.P.; FIALHO, C.A.; DIAS, D.C.F.S. Assessing the physiological quality of common bean seeds using the Vigor-S ${ }^{\circledR}$ system and its relation to the accelerated aging test. Journal of Seed Science, v.41, n.2, p.187-195, 2019. https://doi.org/10.1590/2317-1545v41n2211401

NAKAGAWA, J. Testes de vigor baseados na avaliação de plântulas. In: KRZYZANOWSKI, F.C.; VIEIRA, R.D.; FRANÇA-NETO, J.B. (Ed.). Vigor de sementes: conceitos e testes. Londrina: ABRATES, 1999. p.2.1-2.21.

R CORE TEAM. R Development Core Team. R: a language and environment for statistical computing, 2020. http://www.R-project.org

ROGRIGUES, M.; GOMES-JUNIOR, F.G.; MARCOS-FILHO, J. Vigor-S: system for automated analysis of soybean seed vigor. Journal of Seed Science, v.42, e202042039, 2020. https://doi.org/10.1590/2317-1545v42237490

SAKO, Y.; MCDONALD, M.B.; FUIIMURA, K.; EVANS, A.F.; BENNETT, M.A. A system for automated seed vigour assessment. Seed Science and Technology, v.29, n.3, p.625-636, 2001. https://www.eurofinsus.com/media/162083/seed-vigor-imaging-system.pdf

SILVA, P.P.; BARROS, A.C.S.A.; MARCOS-FILHO, J.; GOMES-JUNIOR, F.G.; NASCIMENTO, W.M. Assessment of squash seed vigor using computerized image analysis. Journal of Seed Science, v.39, n.2, p.159-165, 2017. https://doi.org/10.1590/2317-1545v39n2171177

SMIDERLE, O.J.; SOUZA, A.G.; ALVES, J.M.A.; BARBOSA, C.Z.R. Physiological quality of cowpea seeds for different periods of storage. Revista Ciência Agronômica, v.48, p.817-823, 2017. http://dx.doi.org/10.5935/1806-6690.20170096

WENDT, L.; GOMES-JUNIOR, F.G.; ZORATO, M.F.; MOREIRA, G.C. Avaliação do potencial fisiológico de sementes de soja por meio de imagens. Pesquisa Agropecuária Tropical, v.44, n.3, p.280-286, 2014. https://doi.org/10.1590/S1983-40632014000300011 